\title{
Koncepcja kodów kultury w rosyjskich i ukraińskich badaniach lingwokulturologicznych i etnolingwistycznych ${ }^{1}$
}

W lingwistyce drugiej połowy XX w. pod wpływem antropocentryzmu zmienił się punkt widzenia przedmiotu badań. Język zaczęto rozpatrywać jako produkt kultury oraz jej składnik. Przesunięcie akcentu z języka na kulturę i odwrotnie spowodowało poszerzenie zakresu badań i pojawienie się wielu aspektów problemu związku języka i kultury. Rozwój koncepcji kodów kultury w językoznawstwie rosyjskim (później w ukraińskim) można powiązać z wyodrębnieniem się w latach 90 . XX w. lingwokulturologii ${ }^{2}$ jako oddzielnej dyscypliny językoznawczej, a przede wszystkim ze zmianą kierunku badań:jeżeli do tej pory związek języka i kultury wykorzystywano do rozwiązywania problemów lingwistycznych, to teraz przedmiotem badań lingwokulturologii stały się sposoby ustalania, przechowywania i przekazywania kultury w jednostkach językowych (por. Chubenko, 2006, s. 59; Maslova, 2001, s. 9). We frazeologizmach jakiegokolwiek języka wyraziściej niż w innych znakach językowych przenikają się dwa systemy semiotyczne - język i kultura, co stało się przyczyną intensywnego rozwoju koncepcji kodów kultury w pracach dotyczących frazeologii. Kody kultury w takim kontekście są materiałem wyjściowym dla określenia kulturowej semantyki frazeologizmu, jego analizy jako znaku kultury i języka jednocześnie. Za pomocą kodów kultury wyznaczano i opisywano rolę, jaką odgrywa

\footnotetext{
${ }^{1}$ Pierwotnie koncepcję kodów kultury rozwijano w lingwokulturologicznych pracach dotyczących frazeologii, lecz obecnie, zwłaszcza w badaniach ukraińskich lingwistów, rozpatrywanie zasobu frazeologicznego w kontekście kodów kultury odbywa się z uwzględnieniem dorobku i metod zarówno lingwokulturologii, jak i etnolingwistyki.

${ }^{2}$ Termin lingwokulturologia pojawił się w latach 90. XX w. w pracach moskiewskiej szkoły lingwokulturologicznej analizy frazeologizmów (ros. Московская школа лингвокультурологического анализа фразеологизмов, MSLCFraz) V. N. Teliya.
} 
frazeologizm oraz każdy z jego komponentów w kulturze, będący symbolem, etalonem, stereotypem itp. Celem tego artykułu jest zaprezentowanie osiągnięć współczesnej lingwistyki rosyjskiej i ukraińskiej w zakresie definiowania, wyodrębnienia oraz klasyfikacji kodów kultury, a także zasygnalizowanie problemu braku zgodności przy wyodrębnieniu i definiowaniu kodów kultury.

\section{Co to jest kod kultury?}

W lingwokulturologii termin kod kultury (ros. код культуры) określano w stosunku do dwóch podstawowych pojęć semiotyki - kodu i kultury. Termin kod jako system środków służący do przekazywania informacji (Polański, 1995, s. 273) pierwotnie użyty został przez Claude E. Shannona (1948) do opisu matematycznej teorii komunikacji. Termin ten okazał się przydatny do interpretacji niektórych zagadnień semiotyki. O kodzie jako o strukturze semiotycznej pisali: Roman O. Jakobson (lakobson, 1975), Roland Barthes (Bart, 2001), Umberto Eco (Ėko, 2004), Yury M. Lotman $(2000,2002)$ i in $^{3}$. Biorąc pod uwagę założenie, że kultura to kompleks systemów znakowych, Y. M. Lotman (2002) zdefiniował termin kod kulturowy (ros. культурный код) jako zbiór potrzebnej do istnienia konkretnej kultury informacji, która mieści się w różnych tekstach danej kultury (Lotman, 2002, ss. 18-19). Dalsze zainteresowanie kodami kultury można powiązać z pracami Nikity I. Tolstoya (Tolstol̆, 1995), założyciela moskiewskiej szkoły etnolingwistycznej (ros. Московская этнолингвистическая школа), który, nawiązując do J. M. Lotmana, twierdził, że kultura w znaczeniu semiotycznym jest wielojęzyczna i często łączy w jednym tekście kilka języków ( język w tym kontekście trzeba rozumieć jako system znaków). Rozumiejąc obrzęd jako tekst kultury wyrażony językiem semiotycznym, badacz ten wyróżnił trzy formy, trzy kody i trzy aspekty języka - werbalny (słowa, teksty), rzeczywisty (wizualny - przedmioty, rzeczy) i akcjonalny (działania) (Tolstol̆, 1995, s. 23).

Uwzględniając poprzednie osiągnięcia naukowców w zakresie definiowania terminu kod kultury, Viktoriya V. Krasnykh, reprezentantka moskiewskiej szkoły lingwokulturologicznej (ros. Московская лингвокультурологическая школа), uznaje kody kultury za „sieć", którą kultura „rzuca” na świat, dzieli go, kategoryzuje i wartościuje (Krasnykh, 2002, s. 232). W takim ujęciu kultura jest przestrzenią sensów kulturowych, które powstają w procesie doświadczania świata. Innymi słowy, kultura to przestrzeń kodów - wtórnych systemów

\footnotetext{
${ }^{3}$ O wieloznaczności terminu kod w kontekście kultury pisali Albert K. Bayburin i George A. Lewinton (1998) (za Tolstaia, 2007, s. 23).
} 
znaków, które korzystają z różnych materialnych i formalnych środków do kodowania tej samej treści (Teliia, 1996, s. 217). Zakodowane sensy kulturowe składają się na obraz świata ujawniający światopogląd wspólnoty kulturowej.

Przedstawiciele moskiewskiej szkoły lingwokulturologicznej analizy frazeologizmów (ros. Московская школа лингвокультурологического анализа фразеологизмов MSLCFraz) Dmitry B. Gudkov i Mariya L. Kovshova (2007) uważają, że kod kultury to system znaków świata materialnego i duchowego reprezentujący znaczenia kulturowe odczytywane w tych znakach (Gudkov \& Kovshova, 2007, s. 4). Mogą to być zarówno znaki werbalne, jak i inne (np. materialne), jednak uniwersalnym systemem znaków dla człowieka jest język, dlatego kultura "szuka” znaków do wcielenia swoich sensów wartościowanych w języku, sprzyjającym ich zachowaniu i przekazywaniu.

W językoznawstwie ukraińskim według wydawnictw encyklopedycznych kod kultury to „мережа членування, категоризації, оцінок інтеріоризованого світу та внутрішнього досвіду людини, зумовлена культурою певного етносу й репрезентована в семіотичних системах природної мови, мистецтва, обрядів, звичаїв, вірувань, а також у нормах моралі, поведінці членів етнічної спільноти" (Selivanova, 2006, s. 43) ${ }^{4}$. Z kolei Fedir S. Bacevych uważa, że kod kultury to zbiór znaków (symboli) i ich znaczeń, które są dostępne w jakimkolwiek przedmiocie kultury oddzielnej narodowej wspólnoty lingwokulturowej (Batsevych, 2007). Badacz ten wysnuł wniosek, że kod kultury przejawia się również w języku etnicznym i w językowym obrazie świata.

Reprezentantka symferopolskiej szkoły frazeologicznej (ukr. Сімферопольська фрразеологічна школа) Lyubov V. Savchenko, podzielając pogląd V. N. Teliya, omawianą w tym artykule koncepcję zdefiniowała w następujący sposób: „відповідна національна етнокультурна інформація, що кодується у формі, здатній ідентифікувати культуру, через сукупність вторинних знаків і символів, наділених такими смислами (та їх комбінаціями), які можуть виявлятися в предметах матеріальної і духовної діяльності людини на рівні семіотичного простору" (Savchenko, 2013, s. 62)

Biorąc pod uwagę doświadczenia innych badaczy, L.V.Savchenko wprowadziła termin etnokod kultury (ukr. етнокод культури), który obejmuje etnoelementy kultury duchowej - mity,

\footnotetext{
${ }^{4}$ Tu i dalej w przypisach podaję cytat przetłumaczony przez autora na język polski: ...„sieć podziału, kategoryzacji, wartościowania świata i wewnętrznego doświadczenia człowieka, spowodowana przez kulturę jakiegoś narodu i reprezentowana przez system semiotyczny języka naturalnego, sztukę, obrzędy, zwyczaje, wierzenia i normy zachowania moralnego członków wspólnoty etnicznej" (Selivanova, 2006, s. 43).

5 "kod kultury to odpowiednia narodowa informacja etnokulturowa, która jest kodowana jako forma zdolna identyfikować kulturę przez zbiór wtórnych znaków i symboli (i ich połączeń), które mogą przejawiać się w przedmiotach materialnego i duchowego działania człowieka na poziomie przestrzeni semiotycznej" (Savchenko, 2013, s. 62).
} 
obrzędy, wierzenia, obyczaje (Savchenko, 2013, s. 86). Wyodrębienie etnokodu kultury w takim przypadku odbywa się w przestrzeni etnomakrokodu kultury duchowej (ukr. етномакрокод духовної культури): etnomakrokod (ukr. етномакрокод) $\rightarrow$ etnokod (ukr. етнокод) $\rightarrow$ etnosubkod (ukr. етносубкод) $\rightarrow$ etnomikrokod (ukr. етномікрокод). Nowy termin etnomakrokod kultury duchowej badaczka ta zdefiniowała jako „сукупність образів, що базуються на етнокультурних знаках, пов'язаних із моральними цінностями, настановами і правилами, традиціями і звичаями, віруваннями і повір'ями, обрядово-ритуальними магічними діями, що сформувалися під впливом міфологічних і релігійних (християнських) уявлень" (Savchenko, 2013, s. 83) ${ }^{6}$.

Należy zauważyć, że kody kultury są uniwersalne, jednak ich przejawy, znaczenia w konkretnej kulturze i metafory, w których się realizują, są różne dla poszczególnych narodów (Kovshova, 2009; Batsurèn, 2010; Savchenko, 2013). Wyodrębnienie kodów odbywa się w toku analizy archetypowej, formalnej, dystrybutywnej, etymologicznej, tekstowo-interpretacyjnej, a także przez porównanie kodów innych kultur oraz modelowanie konceptualne (Selivanova, 2006, s. 43). Jednak liczne badania materiału frazeologicznego w systemie kodów kultury wskazują na niemożność ustalenia wyraźnych granic między kodami (Selivanova, 2006, ss. 220-221; Savchenko, 2013, s. 71), ponieważ dość często reprezentacja jednego kodu odbywa się za pomocą znaków innego.

W różnych definicjach kod kultury jest określany jako wtórny system znaków, który na różne sposoby koduje sensy kulturowe, czyli wartościową treść kultury. Biorąc pod uwagę fakt, że zakodowane sensy kulturowe stanowią obraz świata danej społeczności, można wysnuć następujący wniosek: kod kultury funkcjonuje jako sposób opisu światopoglądu wspólnoty kulturowej.

\section{Klasyfikacja kodów kultury}

W językoznawstwie rosyjskim i ukraińskim jest znanych kilka klasyfikacji kodów kultury Wszystkie łączy przekonanie, że przestrzeń kulturowa świata zewnętrznego składa się z przedmiotów, tekstów oraz działań, zaś przestrzeń kulturowa świata wewnętrznego (w mentalności człowieka) istnieje jako suma wiedzy, doświadczeń, doznań, skojarzeń, obrazów itp.

\footnotetext{
6 „połączenie obrazów bazowanych na znakach etnokulturowych, które są związane z moralnymi wartościami, podstawowymi założeniami oraz przepisami, tradycjami i zwyczajami, wierzeniami i przesądami, obrzędowo-rytualnymi magicznymi czynnościami sformowanymi pod wpływem mitologicznych, religijnych (chrześcijańskich) wyobrażeń" (Savchenko, 2013, s. 83).

${ }^{7}$ W niniejszym artykule zaproponowano analizę klasyfikacji kodów kultury, które są najczęściej wykorzystywane przy badaniu frazeologizmów w ujęciu lingwokulturologicznym i etnolingwistycznym. W celu wskazania i zasygnalizowania
} 
Szczególnie ważna jest relacja między znakami świata zewnętrznego a wewnętrznego, na podstawie której kody kultury są dzielone na dwie grupy - substancjonalną i konceptualną ${ }^{8}$ (TSiv'ian, 2005; Berezovich, 2007; Tolstaia, 2008).

W pracach lingwokulturologów najczęściej wykorzystywana jest klasyfikacja przedstawicielki moskiewskiej szkoły lingwokulturologicznej V. V. Krasnykh (2002, ss. 231-255). Badaczka ta wyodrębniła następujące kody kultury: somatyczny (ros. соматический) reprezentujący obrazy przez symbolikę części ciała człowieka, np. ros. золотые руки; przestrzenny (ros. пространственный) - reprezentujący obrazy przez oznaczenie lokalizacji człowieka w przestrzeni, np. ros. в двух шагах; czasowy (ros. временной) - reprezentująсу obrazy przez oznaczenie czasu i umiejscowienia człowieka na osi czasowej, np. ros. do поры до времени; przedmiotowy (ros. предметный) - reprezentujący obrazy przedmiotów rzeczywistości zewnętrznej, np. ros. выносить сор из избы; biomorficzny (ros. биоморфный) reprezentujący obrazy roślin, zwierząt, bestii, np. ros. крепкий как дуб; заблудшая овечка; duchowy (ros. Әуховный) - reprezentujący obrazy związane z wartościami kulturowymi i odzwierciedlony w każdym z wymienionych wyżej kodów.

Zupełnie inne podejście do nazewnictwa odrębnych kodów kultury, a także do ich wyróżniania, zaproponowano w pracach naukowców kazańskiej szkoły frazeologicznej (ros. Казанская фразеологическая школа). Wraz z nimi Guzel A. Bagautdinova w pracy Человек во фразеологии: антропоцентрический и аксиологический аспекты (2007) oprócz kodów kultury wspomnianych już w klasyfikacji V. V. Krasnykh (2002) (ale pod innymi nazwami): geograficznego (ros. географического), czyli przestrzennego, temporalnego (ros. темпорального), poprzednio czasowego, объектного ${ }^{9}$, czyli przedmiotowego, oraz biomorficznego (ros. биоморфного), dodała jeszcze антропоморфный - reprezentujący obraz człowieka i części jego ciała, np. ros. бедовая голова; любопытной Варваре (на базаре) нос оторвали; animiczny (ros. анимический) - reprezentujący obrazy zjawisk przyrody, np. ros. ждать у моря погоды; mitologiczny (ros. мифологический) - reprezentujący obrazy religijnych i nadprzyrodzonych wyobrażeń człowieka oraz obrazy bohaterów bajek, np. ros. мелким бесом рассыпаться; перуны метать; скуп как Кощей; kolorystyczny (ros. колоративный) -

problemu braku zgodności przy wyodrębnieniu kodów kultury nie tylko w inwentarzach, ale i w pojęciach, przeanalizowano i inne, mniej znane klasyfikacje wyraźnie demonstrujące różnorodność myśli we współczesnej lingwistyce.

${ }^{8}$ Niektórzy badacze uważają, że werbalny kod kultury należy rozpatrywać poza systemem substancjonalnych i konceptualnych kodów kultury, ponieważ język to nie tylko sposób komunikacji, ale też „interpretator” kultury (Savchenko, 2013, ss. 63, 67).

${ }^{9} \mathrm{~W}$ przypadku niemożności przetłumaczenia nazwy kodu na język polski podaję ją tylko w zapisie oryginalnym. 
reprezentujący obrazy związane z symboliką koloru, np. ros. в черном цвете; kwantytatywny (ros. квантитативный) - reprezentujący obrazy poprzez jednostki miary, a także ilości, np. ros. одна извилина; terminologiczny (ros. терминологический) - reprezentujący obrazy poprzez terminy wojskowe, sportowe itp., np. ros. nороху не хватает; нажимать на все педали. Pominęła natomiast duchowy kod kultury. Warto zauważyć, że aнmponныŭ kod kultury według G. A. Bagautdinovej, tak samo jak somatyczny w rozumieniu V. V. Krasnykh, reprezentuje obrazy cięści ciała człowieka, jednak ma szerszy zakres, ponieważ reprezentuje jeszcze obraz człowieka w ogóle. Biomorficzny kod kultury w klasyfikacji G. A. Bagautdinovej reprezentuje obrazy roślin i zwierząt. Badaczka nie wymienia tutaj obrazów bestii, jak np. V. V. Krasnykh, lecz zalicza je do kodu mitologicznego. Wyodrębnienie kwantytawnego, terminologicznego kodu kultury spowodowane jest rozpatrywaniem zasobu frazeologicznego związanego z działalnością człowieka.

Przedstawiciele moskiewskiej szkoły lingwokulturologicznej analizy frazeologizmów D. B. Gudkov i M. L. Kovshova (2007), rozpatrując cielesny (ros. телесный, poprzednio somatyczny) kod kultury we frazeologii języka rosyjskiego, wyróżnili i inne kody kultury, będące w relacji z somatycznym, między innymi wspomniane już w tym artykule: przestrzenny (ros. пространственный), сzаsowy (ros. временной), цветовой, czyli wcześniej wymieniony kolorystyczny, oraz przyrodniczy (ros. nрuродный), poprzednio animiczny. Ponadto dodali nowe: антропный - jest wyjaśniany przez tych badaczy właśnie jako ludzki, np. ros. валять дурака; zoomorficzny (ros. зооморфный), np. ros. черная кошка пробежала; roślinny (ros. pастительный), np. ros.хоть трава не расти - należące do zakresu wymienionego wyżej biomorficznego kodu kultury; артефрактно-вещный, np. ros. до лампочки; rzeczowo-ubraniowy (ros. вещно-костюмный), np. ros. под каблуком; религиозно-артефактивный, np. ros. дышать на ладан; gastronomiczny (ros. гастрономический), np. ros. каша в голове; architektoniczny (ros. архитектурный), np. ros. крыша edem - należące do zakresu przedmiotowego kodu kultury; ilościowy (ros. количественный), reprezentujący obrazy przez symbolikę liczb, np. ros. как дважды два; duchowo- albo religijno-antropomorficzny (ros. духовно- / религиозно-антропоморфный) reprezentująсу ogół moralnych norm człowieka; obrazy demonicznych istot o charakterze mitologicznym i religijnym, a także ich atrybuty, np. ros. nо душам; мешать божий дар с яичницей; черт его знает (zob. Gudkov \& Kovshova, 2007, ss. 96-99).

W nurcie badań szkoły frazeologicznej V. N. Teliya Renchin Batsuren (Batsurèn, 2010) dokonała analizy porównawczej językowego obrazu świata, opierając się na materiale 
frazeologicznym trzech języków (angielskiego, rosyjskiego i mongolskiego), i wyodrębniła 16 kodów kultury. Oprócz już wspomnianych wymieniła dodatkowo kody: akcjonalny (ros. деятельностный) - reprezentujący obrazy działań, akcji, np. ros. черная кошка пробежала; jakościowy (ros. качественный) - reprezentujący obrazy związane z cechami charakteru człowieka, np. ros. шальная голова; wagowy (ros. весовой) - reprezentujący obrazy związane z wagą człowieka, np. ros. кожа да кости, czyli 'chudy'. Warto zaznaczyć, że wyodrębnienia kodów kultury przez R. Batsuren dokonano, analizując frazeologizmy o znaczeniu 'chudy', 'gruby' (figura człowieka); frazeologizmy z komponentami голова, ноги, руки, глаза (zewnętrzne charakterystyki człowieka); frazeologizmy z komponentem cepдue (wewnętrzne osobliwości człowieka); frazeologizmy z animalistycznym komponentem (człowiek w relacji ze światem żywych istot) (zob. Batsurèn, 2010, ss. 9-17).

W duchu moskiewskiej szkoły etnolingwistycznej (ros. Московская етнолингвистическая школа) N. I. Tolstoya zasób leksykalny, w tym i frazeologiczny, bada Tatyana V. Leontyeva (Leont'eva, 2003). Uczona ta, analizując pole znaczeniowe „intelekt człowieka”, odniosła się do 14 przedmiotowo-tematycznych ${ }^{10}$ kodów kultury, znanych z wcześniejszych prac. Wydzieliła też nowe: mowny (ros. речевой) - reprezentujący obrazy związane z procesem mówienia; społeczny (ros. сочиальный) - reprezentujący obrazy dotyczące określeń człowieka w społeczeństwie i techniczny (ros. технический) - reprezentujący obrazy związane z nazwami wytworów techniki. Warto zauważyć, że brak w tej klasyfikacji bazowych kodów kultury, takich jak czasowy czy duchowy, obecne są natomiast kody mowny, społeczny, techniczny, co jest spowodowane zakresem badań, dotyczącym wyłącznie pola znaczeniowego „intelekt człowieka”.

W ukraińskich badaniach klasyfikacje kodów kultury mają dużo wspólnego z klasyfikacjami lingwokulturologów rosyjskich, jednak i tu są różnice. W encyklopedii Сучасна лінгвістика: термінологічна енциклопедія Olena O. Selivanova (2006), podobnie jak V.V. Krasnykh (2002), do najważniejszych kodów zaliczyła somatyczny (ukr. соматичниŭ), przestrzenny (ukr. nросторовий), сzаsоwy (ukr. часовий) i duchowy (ukr. духовний), a biomorficzny podzieliła z kolei na zoomorficzny (ukr. зооморфічний) i roślinny (ukr. рослинний). Wymieniła również kody aнmропний, akcjonalny (ukr. акціональний), religijny (ukr. релігійний), a także kosmologiczny (ukr. космогонічний) - reprezentujący obrazy przestrzeni kosmologicznej,

\footnotetext{
${ }^{10}$ Według T. W. Leontyevej (Leont'eva, 2003) przedmiotowo-tematyczny kod kultury oznacza pewne sfery ustalania tożsamości, przedmiotowe "języki", pośrednio mówiące o jakimkolwiek zjawisku oraz dostarczające "surowce" do konkretnych obrazów i metafor.
} 
np. ukr. зірок з неба не хапати; aksjologiczny (ukr. аксіологічний) - reprezentujący obrazy dotyczące procesu wartościowania, np. ukr. чорні дні; sensorowy (ukr. сенсорний) - reprezentujący obrazy uczuć, np. ukr. до крику (Selivanova, 2006, s. 202).

W Словнику термінів міжкультурної комунікації (Batsevych, 2007) F. S. Bacevych podał definicje następujących kodów kultury: biomorficznego (ukr. біоморфний), duchowego (ukr. духовний), przedmiotowego (ukr. предметний) і somatycznego (ukr. соматичнuй). Warto zauważyć, że duchowy kod kultury według tego badacza to kod, w którym odzwierciedlają się wartościowanie i normy moralne oraz związane z nimi bazowe opozycje kultury, np. dobro - zło i in. (Batsevych, 2007). Te uwagi zgadzają się z rozumieniem kodu duchowego zaproponowanym przez V. V. Krasnykh (2002). Jednak O. O. Selivanova (2004), wymieniając kod duchowy i aksjologiczny, w takim znaczeniu rozumiała właśnie kod aksjologiczny, a nie duchowy. Z prac tej badaczki wynika, że duchowy kod kultury jest pojmowany jako interpretator wewnętrznego świata człowieka, jego odczuć, przeżyć itp., np. ukr. солити рани душі w znaczeniu 'przywoływać ciężkie wspomnienia, przypominając o tym, co martwi; wywoływać ból serca' (Selivanova, 2010).

\section{Próba pogodzenia różnych stanowisk}

Powstanie zróżnicowanych klasyfikacji kodów kultury jest spowodowane rozmaitym charakterem rozpatrywanego przez badacza materiału językowego, który jest klasyfikowany według tematu. Wskutek tego podstawową klasyfikację kodów kultury ciągłe uzupełniano innymi kodami, niezbędnymi dla prowadzenia analizy i opisu kulturowej semantyki badanych jednostek. Próbę pogodzenia różnych stanowisk zaproponowała L. V. Savchenko (2013), reprezentantka symferopolskiej szkoły frazeologicznej. Przedmiotem jej badań stał się system etnokodów i kodów kultury oraz ich korelacja z obrazami, semantyką i komponentami etnofrazeologizmów w aspekcie mentalnym, akcjonalnym oraz werbalnym. Uwzględniając prace innych badaczy, L. V. Savchenko zaproponowała kolejną klasyfikację kodów kultury. Jej podstawą są dwie grupy: substancjonalna i konceptualna, a także werbalny (ukr. веpбальний) kod kultury. Do substancjonalnych kodów L. V. Savchenko zalicza: антропний, somatyczny (ukr. соматичний), zoomorficzny (ukr. зооморфний), fitomorficzny (ukr. pimoморфний), przedmiotowy (ukr. предметний) oraz przyrodniczy (ukr. природний), z których każdy ma swój subsystem i mikrosystem. O wszystkich wymienionych kodach substancjonalnej grupy powiedziano wcześniej (fitomorficzny w innych klasyfikacjach ma nazwę 
roślinny), ponieważ rozpatrywali je inni badacze. Nie dokonali oni jednak tak dokładnego opisu systemu każdego kodu jak L. V. Savchenko. Do konceptualnych należą: cnamiaльний - w innych klasyfikacjach przestrzenny; temporalny (ukr. темпоральний) - w innych klasyfikacjach czasowy; geometryczny (ukr. геометричний) - reprezentujący obrazy figur geometrycznych, np. ukr. пускати по колу; kolorystyсzny (ukr. колоративний), kwantytatywny (ukr. квантитативний) - w innych klasyfikacjach ilościowy; моторіальний - reprezentujący obrazy związane z procesem ruchu, np. ukr. аж іскри летять; kauzatywny (ukr. каузативнuй) - reprezentujący obrazy wyjaśniające przyczyny różnych zjawisk, np. ukr. за красиві очi; aksjologiczny (ukr. аксіологічний), кваліфікативний - reprezentująсу obrazy sformowane na podstawie wiedzy o wyróżniających cechach obiektów w rzeczywistości, które służą do odróżnienia albo porównania zjawisk, np. ukr. довга пісня; короткі жарти (Savchenko, 2013, ss. 94-147). Należy zauważyć, że w systemie konceptualnych kodów kultury w opisywanej klasyfikacji nie ma subsystemu i mikrosystemu, które są obecne w substancjonylnych kodach kultury.

Ponadto L. V. Savchenko (2013) przedstawiła klasyfikację etnomakrokodu kultury duchowej, który w aspekcie mentalnym składa się z etnokodów: mitologicznego (ukr. міфологічний), który reprezentuje ogół archaicznych pierwotnych wyobrażeń religijnych człowieka, np. ukr. на чім світ стоїть; пройти крізь чистилище; еtiologicznego (ukr. етіологічний), który reprezentuje wyobrażenia ludowe o przyczynach chorób, ich animizację, np. ukr. холера його принесла; хай йому грець; demoniczno-antropomorficznego (ukr. демонологічно-антропоморфний), który reprezentuje zespół mitologicznych wyobrażeń o istotach demonicznych, np. ukr. завести в блуд; біс узяв; etnokodu przesq̨dów (ukr. етнокод повір'я (прикмет)), który reprezentuje wyobrażenia ludowe, które są realizowane w przesądach opartych na wątkach mitologicznych, np. ukr. встати на ліву ногу; religijnego (ukr. релігійний), który reprezentuje ogół chrześcijańskich wyobrażeń o istnieniu dwóch światów, roli Boga w tym hierarchicznym systemie i duszy jako najwyższej substancji ludzkiej, np. ukr. кара Божа; душа відлетіла; w aspekcie akcjonalnym - tradycyjno-obrzędowego (ukr. традиційно-обрядовий) - reprezentuje obrazy fragmentów ważnych wydarzeń życiowych, którym towarzyszą obrzędy kalendarzowe, rodzinne, kościelne itd., np. ukr. проганяти кутю; носити жалобу; zwусzаjowego (ukr. звичаєвий) - reprezentuje przekonania światopoglądowe, które są zakorzenione jako niepisane zasady, funkcjonują w społeczeństwie i których trzeba koniecznie przestrzegać, np. ukr. голити лоба; копати Петра; rytualnego (ukr. ритуальний) - reprezentuje zespół obrazów symbolizującego zachowania człowieka, 
które składa z się z systemu działań i towarzyszących im magicznych tekstów, np. pвamu на собі волосся; etnokodu wróżby (ukr. етнокод ворожіння) - reprezentuje ogół wyobrażeń związanych z praktykami magicznymi, przepowiedniami, np. ukr. як у воду дивився; чудо в решеті; w aspekcie werbalno-akcjonalnym - etnokodu zamawiań (ukr. етнокод замовлянь) - reprezentuje przekonania o ludowych praktykach leczniczo-magicznych polegających na wypowiadaniu zamów, zaklęć w celu przezwyciężenia choroby, np. ukr. заговорювати зуби; переливати з пустого в порожнє; etnokod przysięgi (ukr. етнокод клятви (присяги, божб()) - reprezentuje ogół obrazów związanych z symbolicznym zachowaniem człowieka (różne działania, w tym wymawianie magicznych tekstów) podczas składania przysięgi, np. ukr. ось тобі хрест; ручатися головою; etnokod przekleństw (ukr. етнокод проклять) - reprezentuje zespół obrazów stworzonych w wyobraźni człowieka na podstawie wierzeń, które są zakodowane w magicznych tekstach werbalnych wyrażających życzenia negatywne, np. ukr. щоб грім убив кого; щоб на тебе образи падали; оraz етикетний etnokod - reprezentuje ogół obrazów stereotypów, które są zakodowane w magicznych tekstach werbalnych jako pozytywne życzenia albo działania, np. ukr. знімати капелюха; бувайте здорові. Oprócz tego wskazano na istnienie w systemie etnomakrokodu kultury duchowej, ale nie rozpatrywano etnokodów: дозвілля - reprezentujący obrazy związane ze spędzaniem wolnego czasu (np. gry, tańce ludowe), np. ukr. битися навбитки; бити третяка; moralny (ukr. моральний) - reprezentujący obrazy postępowania według norm moralności, np. ukr. з чистим сумлінням; oraz społeczny (ukr. сочіальний) - reprezentująсу obrazy związane z zachowaniem człowieka w społeczeństwie, np. ukr. світська левиця (Savchenko, 2013, ss. 86-89).

\section{Perspektywy badawcze}

Badanie związków frazeologicznych motywowanych kulturą duchową pozwoliło L. V. Savchenko dokonać dokładnego podziału kodów kultury i wyodrębnić nowe. Podana klasyfikacja kodów i etnokodów kultury jest obecnie najobszerniejsza w językoznawstwie ukraińskim i rosyjskim. Oprócz tego L. V. Savchenko podkreśliła, że podczas badania frazeologizmów motywowanych kulturą duchową istotne jest wzajemne oddziaływanie etnokodów i kodów kultury. Frazeologizmy reprezentujące kulturę duchową odtwarzają pewne kodowane indeksy transformacji informacji kulturowej, które są wyjawiane na tle formalnego, semantycznego lub obrazowego poziomu korelacji kodów kultury w jednostce frazeologicznej. 
Każdy komponent frazeologizmu i jego semantyka odpowiadają więc pewnemu kodowi, a obraz - etnokodowi kultury (Savchenko, 2013, ss. 89-92). Dzięki temu istnieje możliwość dokonania wyczerpującej analizy etnokulturowej treści frazeologizmu poprzez połączenie etnokodów i kodów kultury.

Z przeglądu prac teoretycznych dotyczących wyodrębniania oraz klasyfikacji kodów kultury wynika, że we współczesnym językoznawstwie rosyjskim i ukraińskim istnieje wiele różnych klasyfikacji, które uwzględniają substancjonalną i konceptualną rozmaitość znaków przestrzeni kulturowej. W badaniach zasobu frazeologicznego w ujęciu lingwokulturologicznym znaki kulturowe o różnej substancji łączono w kody kultury według tematu. Różnice między analizowanymi klasyfikacjami dotyczą nie tylko liczby wyodrębnianych kodów (6, 14, 15, 16 itd.), ale też ich nazewnictwa, ponieważ kod kultury kodujący tę samą treść w klasyfikacjach różnych autorów ma różne nazwy (np. botaniczny i roślinny; artefaktualny i przedmiotowy) albo odwrotnie - pod tą samą nazwą kryje się zupełnie inna treść (np. duchowy, jakościowy). Próbę połączenia i unifikacji różnych podejść do klasyfikacji kodów kultury podjęła L. V. Savchenko (2013), jednak i tu pojawiają się pewne niedopracowania, np. system konceptualnych kodów kultury jest pozbawiony subsystemu i mikrosystemu; nie zostały opisane kody społeczny i moralny itd. Na tej podstawie można wnioskować, że brak jest zgodności co do klasyfikacji kodów kultury. Otwarte pozostaje także pytanie, jak ujednolicić terminologię koncepcji kodów kultury. Wydaje sie, że potrzebne jest przyjęcie przez naukowców jednej podstawowej klasyfikacji kodów kultury z jednolitymi terminami.

Zaprezentowane osiągnięcia językoznawców w zakresie definiowania, wyodrębniania oraz klasyfikacji kodów kultury są niezbędne dla prowadzenia kolejnych badań dotyczących np. zarysowania zakresu mitologicznego kodu kultury, analizy i opisu jednostek frazeologicznych motywowanych mitologicznym kodem kultury z uwzględnieniem międzykodowych przejść, a także modeli połączenia kodów kultury w strukturze frazeologizmów.

\section{Bibliografia}

Bagautdinova, G. A. (2007). Chelovek vo frazeologii: Antropotsentricheskii i aksiologicheskii aspekty (Autoref. dys.... dr. filol. nauk). Kazan'. Pobrano z http://cheloveknauka.com/chelovek-vo-frazeologii Baĭburin, A. K., \& Levinton, G. A. (1998). Kod(y) i obriad(y). W D. Ajdačić (Red.), Kodovi slovenskih kultura (ss. 239-257). Beograd: Clio.

Bart, R. (2001). S/Z. Moskva: Ėditorial. 
Batsevych, F. S. (2007). Slovnyk terminiv mizhkul'turnoï komunikatsiï. Pobrano z http://terminy-mizhkult-komunikacii.wikidot.com/k

Batsurèn, R. (2010). Otobrazhenie universal'nykh i ètnospetsificheskikh chert iazykovoi kartiny mira $v$ frazeologicheskikh fondakh angliiskogo, russkogo i mongol'skogo iazykov: (na materiale frazeologizmov-somatizmov i zoonimov) (Autoref. dys. ... kand. filol. nauk). Saratov. Pobrano z http://cheloveknauka.com/otobrazhenie-universalnyh-i-etnospetsificheskih-chert-yazykovoy-kartiny-mira-v-frazeologicheskih-fondah-angliyskogo-russk

Berezovich, E. L. (2007). lazyk i traditsionnaia kul'tura. Moskva: Indrik.

Chubenko, K. V. (2006). Linhvokul'turolohiia z pohliadu istoriohrafiï. Novitnia filolohiia, 4(24), 57-70.

Ėko, U. (2004). Otsutstvuiushchaia struktura: Vvedenie v semiologiiu. Sankt-Peterburg: Azbuka-klassika.

Gudkov, D. B., \& Kovshova, M. L. (2007). Telesny̌̌ kod russkǒ kul'tury: Materialy k slovariu. Moskva: Gnozis.

lakobson, R. O. (1975). Lingvistika i poètika. W E. I. Basin \& M. I. Poliakov (Red.), Strukturalizm: "Za" i „protiv" (ss. 193-230). Moskva: Progress.

Kovshova, M. L. (2009). Semantika i pragmatika frazeologizmov: Lingvokul'turologicheskiĭ aspekt (Autoref. dys. ... dr. filol. nauk). Moskva. Pobrano z http://cheloveknauka.com/semantika-i-pragmatika-frazeologizmov

Krasnykh, V. V. (2002). Ėtnopsikholingvistika i lingvokul'turologiia. Moskva: Gnozis.

Leont'eva, T. V. (2003). Intellekt cheloveka v zerkale russkogo iazyka (Autoref. dys. ... kand. filol. nauk). Ekaterinburg. Pobrano z http://cheloveknauka.com/intellekt-cheloveka-v-zerkalerusskogo-yazyka

Lotman, I. M. (2000). Semiosfera. Peterburg: Iskusstvo - SPB.

Lotman, I. M. (2002). Istoriia i tipologiia russkoĭ kul'tury. Sankt-Peterburg: Iskusstvo - SPB.

Maslova, V. A. (2001). Lingvokul'turologiia. Moskva: Izdatel'skiĭ tsentr "Akademiia”.

Polański, K. (Red.). (1995). Encyklopedia językoznawstwa ogólnego. Wrocław, Warszawa, Kraków: Zakład Narodowy im. Ossolińskich.

Savchenko, L. V. (2013). Fenomen etnokodiv dukhovnoï kul'tury u frazeolohiï ukraïns'koï movy: Etymolohichnyï ta etnolinhvistychnyı̆ aspekty. Simferopol': Dolia.

Selivanova, O. O. (2004). Narysy z ukraïns'koï frazeolohiï (psikhokognityvnyı̆ ta etnokul'turnyı aspekty). Kÿ̈v-Cherkasy: Brama.

Selivanova, O. O. (2006). Suchasna linhvistyka: Terminolohichna entsyklopediia. Poltava: Dovkillia-K. Selivanova, O. O. (2010). Sensornyı̌ kul'turnyı̌ kod v ukraïns'kykh frazemakh. Pobrano z http:// archive.nbuv.gov.ua/portal/soc_gum./VKnlu/fil/2010_2/Selivanova.pdf

Shannon, C. (1948). A mathematical theory of communication. Bell System Technical Journal, 27(4), 379-423, 623-656. http://doi.org/10.1002/j.1538-7305.1948.tb00917.x

Teliia, V. N. (1996). Russkaia frazeologiia. Moskva: lazyki russkoŏ kul'tury. 
Tokareva, I. I. (2013). Kul'tura kak ob"ekt lingvodidaktiki. Izvestiia Tul'skogo gosudarstvennogo universiteta. Gumanitarnye nauki, (1), 283-292.

Tolstaia, S. M. (2007). K poniatiiu kul'turnykh kodov. W N. B. Vakhtin \& G. A. Levinton (Red.), Sbornik statě k 60-letiiu A. K. Baiburina (ss. 23-31). Sankt-Peterburg: Izdatel'stvo Evropeǐskogo universiteta v Sankt-Peterburge.

Tolstaia, S. M. (2008). Prostranstvo slova: Leksicheskaia semantika v obshcheslavianskoi perspeks tive. Moskva: Indrik.

Tolstol̆, N. I. (1995). lazyk i narodnaia dukhovnaia kul'tura: Ocherki po slavianskoĭ mifologii i ètnolingvistike. Moskva: Indrik.

TSiv'ian, T. V. (2005). Model' mira i ee lingvisticheskie osnovy. Moskva: KomKniga.

\section{The concept of cultural codes in Russian and Ukrainian linguoculturological and ethnolinguistic studies}

This article presents the concept of cultural codes which was earlier discussed in the works of Russian and Ukrainian scholars in the fields of ethnolinguistics and linguoculturological perspectives. The key linguoculturological terms, such as cultural code and ethnocode, are explained. The author of this article has analysed the existing Ukrainian and Russian linguistics theoretical basics of defining, isolating and classifying cultural codes.

\section{Keywords:}

cultural code; ethnocide; phraseology; ethnolinguistic; linguoculturology

\section{Koncepcja kodów kultury w rosyjskich i ukraińskich badaniach lingwokulturologicznych $i$ etnolingwistycznych}

W artykule podjęto próbę zaprezentowania koncepcji kodów kultury rozwiniętej w pracach rosyjskich i ukraińskich lingwistów. Należytą uwagę zwrócono na wyjaśnienie kluczowych pojęć lingwokulturologii, a mianowicie kod kultury, etnokod kultury. Poddano analizie istniejące teoretyczne podstawy definiowania, wyodrębniania oraz klasyfikacji kodów kultury znane w językoznawstwie ukraińskim i rosyjskim.

\section{Słowa kluczowe:}

kod kulturowy; etnokod; frazeologia; etnolingwistyka; lingwokulturologia 